Volume. 8 Nomor. 1, Oktober 2020. p - 2354-8649 I e - 2579-5767

Open Access at: http://ojs.umrah.ac.id/index.php/selat

DOI: https://doi.org/10.31629/selat.v8i1.2781

\title{
KOMPARASI KEWENANGAN EKSEKUTIF DALAM PEMBENTUKAN UNDANG-UNDANG PADA SISTEM PEMERINTAHAN PRESIDENSIL: ANTARA INDONESIA DENGAN AMERIKA
}

\author{
${ }^{1}$ Dania Shofi Maziyah, Xavier Nugraha ${ }^{2}$ \\ ${ }^{12}$ Fakultas Hukum, Universitas Airlangga \\ Jl. Dharmawangsa Dalam Selatan, Airlangga, Kec. Gubeng, Kota Surabaya \\ xavier.nugraha-2015@fh.unair.ac.id
}

\begin{abstract}
Each country is unique in running its system of government. One of these uniqueness is related to the executive's authority in the formation of laws, where even though the State both uses a presidential system of government, there are differences in authority. This difference can be seen in Indonesia and America, where even though these countries both use a presidential system of government, there are differences in executive authority. In order to understand the ratio legis, there are differences, even though the 2 (two) countries both use presidential government systems, this research was conducted. The formulation of the problems in this study are 1) the characteristics of the presidential government system and 2) the authority of the president as an executive in the formation of laws in the presidential system in Indonesia and the United States. This research is a legal research with a statutory approach, a conceptual approach, and a comparative approach.
\end{abstract}

Keyword; United States, Indonesia, Formation of laws, Presidential System

\begin{abstract}
Abstrak
Setiap Negara memiliki keunikan dalam menjalankan sistem pemerintahannya. Salah satu keunikan tersebut adalah berkaitan dengan Kewenangan eksekutif dalam pembentukan undang-undang, dimana meskipun Negara tersebut sama-sama menggunakan sistem pemerintahan presidensil, akan tetapi terdapat perbedaan kewenangan. Perbedaan tersebut dapat dilihat pada Negara Indonesia dan Amerika, dimana meskipun Negara ini sama-sama menggunakan sistem pemerintahan presidensil, namun terdapat perbedaan kewenangan eksekutifnya. Dalam rangka memahami ratio legis adanya perbedaan, meskipun 2 (dua) Negara tersebut samasama menggunakan sistem pemerintahan presidensil, maka penelitian ini dilakukan. Adapun rumusan masalah dalam penelitian ini adalah 1) Karakteristik sistem pemerintahan presidensiil dan 2) Wewenang Presiden sebagai eksekutif dalam pembentukan undang-undang pada sistem presidensiil di Indonesia dan Amerika Serikat. Penelitian ini adalah peneltiain hukum dengan pendekatan peraturan perundang-undangan (statute approach), pendekatan konseptual (conceptual approach), dan pendekatan komparasi (comparative approach).
\end{abstract}


Kata Kunci; Amerika Serikat, Indonesia, Pembentukan undang-undang, Sistem Presidensil.

\section{PENDAHULUAN}

Dalam sistem pemerintahan negara dikenal adanya teori pembagian kekuasaan yang dikemukakan oleh John Locke. ${ }^{1}$ Menurut John Locke, fungsi-fungsi kekuasaan negara itu meliputi fungsi legislatif, fungsi eksekutif, dan fungsi federatif. ${ }^{2}$ Teori yang dikemukakan oleh John Locke tersebut kemudian disempurnakan oleh Charles Secondat Baron de Labrede et de Montesquieu dalam karyanya L'Espirit des Lois (The Spirit of the Laws). Montesquieu berpendeapat, bahwa kekuasaan untuk memerintah negara, seharunys dilaksanakan oleh masing-masing badan yang berdiri sendiri. Ajaran ini kemudian dikenal dengan sebutan Trias Politika. ${ }^{3}$ Dalam ajaran tersebut, Montesquieu berpendapat bahwa:4 "Apabila kekuasaan negara itu dipisahkan secara tegas menjadi tiga, yaitu: kekuasaan perundang-undangan, kekuasaan melaksanakan pemerintahan, dan kekuasaan kehakiman, dan masing-masing kekuasaan itu dipegang oleh badan yang berdiri sendiri. Hal ini akan menghilangkan kemungkinan timbulnya tindakan yang sewenang-wenang dari seorang penguasa, atau tegasnya tidak memberikan kemungkinan dilaksanakannya sistem pemerintahan absolutisme."

Kekuasaan legislatif (rule making function) merupakan kekuasaan negara dalam membentuk undang-undang, kekuasaan ekskekutif (rule application function) merupakan kekuasaan negara untuk menjalankan undang-undang. dan kekuasaan yudisiil (rule adjudication function) merupakan kekuasaan negara untuk mengadili atas pelanggaran undang-undang. ${ }^{5}$ Pemisahan yang tegas antara cabang kekuasaan eksekutif dan cabang kekuasaan legislatif menjadi titik penting guna menjelaskan fungsi legislasi dalam sistem pemerintahan presidensil. Menurut Jhon H.Garvey dan

\footnotetext{
1 Suparto, “Teori Pemisahan Kekuasaan Dan Konstitusi Menurut Negara Barat Dan Islam,” Hukum Islam 19, no. 1 (2019): 134-149.

2 Zulkarnaen, "Kemitraan Antara Eksekutif Dan Legislatif Dalam Sistem Pemerintahan Indonesia Berdasarkan Undang-Undang Dasar Tahun 1945," Galuh Justisi 8, no. 2 (2020): 245-260.

3 Risdiana Izzaty and Xavier Nugraha, "Perwujudan Pemilu Yang Luber Jurdil Melalui Validitas Daftar Pemilih Tetap," Jurnal Suara Hukum 1, no. 2 (2019): http://jurnal.untagsmg.ac.id/index.php/mia/article/view/726.

4 Andy Wiyanto, "Pertanggungjawaban Presiden Dan Mahkamah Konstitusi," Jurnal Konstitusi 7, no. 3 (2010): 209-231.

5 Syofyan Hadi, "Fungsi Legislasi Dalam Sistem Pemerintahan Presidensil (Studi Perbandingan Indonesia Dan Amerika Serikat)," DIH Jurnal Ilmu Hukum 9, no. 18 (2013): 78-84.
} 
T. Alexander Aleinikoff, terdapat 4 (empat) konsekuensi dari pemisahan kekuasaan yang tegas antara eksekutif dan legislatif ada dalam fungsi legisasi, yaitu: 6

1. The Supremacy Of Statute;

2. The Necessity For Legislation;

3. The Non Delegation Function; and

4. The Legislative Veto.

Salah satu contoh Sistem presidensiil murni yang banyak dianggap sebagai "role model" adalah pemerintahan Amerika Serikat. Menurut Bagir Manan, pada sistem presidensil pemerintahan Amerika Serita, memiliki ciri-ciri: ${ }^{7}$

a) Presiden adalah pemegang kekuasaan eksekutif tunggal;

b) Presiden adalah penyelenggara pemerintahan yang bertanggung jawab di samping berbagai wewennag konstitusional yang bersifat prerogatif yang lazim melekat pada jabatan kepala Negara;

c) Presiden tidak bertanggung jawab kepada badan perwakilan rakyat (kongres), karena itu tidak dapat dikenai mosi tidak percaya;

d) Presiden tidak dipilih dan tidak diangkat oleh kongres, dalam praktik langsung oleh rakyat; dan

e) Presiden dapat diberhentikan melalui proses impeachment.

Menurut Bagir Manan, sistem presidensil di Indonesia pada awalnya mempunyai ciri yang hampir mirip dengan sistem di Amerika Serikat, namun hal tersebut berubah sejak adanya amandemen di dalam Undang-Undang Dasar 1945 (UUD 1945). Pasca adanya amandemen UUD 1945 menjadi Undang-Undang Dasar Negara Republik Indonesia Tahun 1945 (UUD NRI 1945), Sistem Presidensil di Indonesia menjadi bersifat tidak murni. ${ }^{8}$ Hal ini disebabkan tercampurnya dengan elemen-elemen sistem parlementer. Hal ini misal dapat dilihat dalam Pasal 5 jo. Pasal 20 UUD NRI 1945 yang memberikan kewenangan kepada Presiden untuk mengusulkan dan terlibat dalam pengesahan undang-undang.

Jika melihat pada negara-negara lain yang menerapkan sistem presidensil, sejatinya pemberian kewenangan bagi Presiden untuk terlibat dalam pembentukan

6 Saldi Isra, Pergeseran Fungsi Legislasi; Menguatnya Model Legislasi Parlementer Dalam Sistem Presidensial Indonesia (Jakarta: PT. Raja Grafindo Persada, 2010):234.

7 Bagir Manan, Lembaga Kepresidenan (Yogyakarta: Gama Media, 1999):50.

${ }^{8}$ Abdul Bari Azed, "Mewujudkan Sistem Presidensial Murni Di Indonesia: Sebuah Gagasan Penyempurnaan Sistem Ketatanegaraan Indonesia" 5, no. 2 (2013): 44-78. 
undang-undang memang memang mulai dikenal. Negara-negara yang menerapkan system presidensil tersebut, seolah-olah memberikan "kewenangan eksklusif" kepada Presiden. Hal ini bisa dilihat dari kewenangan Presiden di beberapa Negara seperti: ${ }^{9}$

1. Kewenangan yang bersifat eksekutif atau menyelenggarakan pemerintahan berdasarkan konstitusi.

2. Kewenangan yang bersifat legislatif atau untuk mengatur kepentingan umum atau publik (to regulate public affair based on the law and the constitution). Dalam sistem pemisahan kekuasaan, kewenangan untuk mengatur dianggap ada di tanagn lembaga perwakilan, bukan di tangan eksekutif. Sehingga, jika lembaga eksekutif merasa perlu mengatur, maka ewenangan mengatur di tangan eksekutif itu bersifat derivatif dari kewenangan legislatif.

3. Kewenangan yang bersifat judisial dalam rangka pemulihan keadilan yang terkait dengan putusan pengadilan. Seperti kewenangan untuk memberikan grasi, abolisi dan amnesti.

4. Kewenangan yang bersifat diplomatik.

5. Kewenangan yang bersifat administratif untuk mengnagkan dan memebrhentikan orang dalam jabatan kenegaraan (Presiden sebagai kepala eksekutif).

6. Kewenangan dalam bidang keamanan dan pertahanan.

Seperti telah disebutkan sebelumnya bahwa pada sistem presidensil, pembentukan peraturan perundang-undangan merupakan wewenang eksklusif dari lembaga legislatif, hal ini didasarkan pada prinsip kedaulatan rakyat. Akan tetapi, ternyata seiring perkembangannya, fungsi legislasi sendiri tidak mutlak menjadi wewenang badan legislatif, namun juga dilakukan bersama dengan kekuasaan eksekutif. Bahkan tidak jarang, kekuasaan eksekutif lebih dominan dalam menjalankan fungsi legislasi. Bahkan jika melihat pada praktik ketatanegaraa dewasa ini, cabang-cabang kekuasaan lainnya juga dapat memiliki kewenangan untuk mengatur atau menetapkan peraturan yang juga mengikat untuk umum, apabila para

\footnotetext{
9 Laurensius Arliman S, "Penyelenggaraan Sistem Presidensil Berdasarkan Konstitusi Yang Pernah Berlaku Di Indonesia," Muhakkamah 4, no. 2 (2019): 77-89.
} 
wakil rakyat telah memberikan persetujuannya dalam undang-undang. ${ }^{10}$ Oleh karena itu, apabila mendapat pendelegasian kewenangan, cabang kekuasaan eksekutif dan yudisiil juga dapat membuat peraturan.

Pembahasan yang akan diuraikan dalam tulisan ini dibatasi pada aspek fungsi legislasi dalam sistem pemerintahan presidensiil dan sejauh mana wewenang Presiden selaku badan eksekutif dalam melakukan fungsi legislasi tersebut. Untuk dapat menemukan penjelasan terhadap permasalahan tersebut, penulis menggunakan analisis komparatif sebagai sarana untuk menjelaskan bagaimana proses pembentukan undang-undang pada sistem pemerintahan presidensiil khususnya mengenai kewenangan Presiden sebagai badan eksekutif. Indonesia dan Amerika Serikat menjadi relevan untuk dibandingkan, karena kedua negara tersebut memiliki kesamaan dalam bentuk sistem pemerintahan, yaitu menganut sistem pemerintahan presidensiil. Terlebih lagi, Amerika Serikat yang dianggap sebagai acuan sistem presidensiil bagi negara-negara di dunia. Sementara Indonesia dalam prosesnya masih mendapat sedikit pengaruh sistem parlementer.

Artikel ini akan mencoba melihat bagaimana pemerintah nasional pada negara dengan sistem presidensiil melakukan proses penyusunan peraturan perundangundangan dengan melakukan analisis komparatif antara Indonesia dan Amerika Serikat. Berdasarkan latar belakang tersebut, maka rumusan masalah dalam artikel ini adalah:

1. Karakteristik sistem pemerintahan presidensiil

2. Wewenang Presiden sebagai eksekutif dalam pembentukan undang-undang pada sistem presidensiil di Indonesia dan Amerika Serikat

Tujuan dari penelitian ini adalah untuk:

1. Menganalisis Karakteristik sistem pemerintahan presidensiil

2. Menganalisis Wewenang Presiden sebagai lembaga eksekutif dalam pembentukan undang-undang pada sistem presidensiil di Indonesia dan Amerika Serikat.

10 Victor Imanuel W Nalle, “Kewenangan Yudikatif Dalam Pengujian Peraturan Kebijakan,” Jurnal Yudisial 6, no. 1 (2013): 33-47. 


\section{METODE PENELITIAN}

Penelitian ini adalah penelitian hukum atau yang dalam Bahasa Inggris disebut sebagai legal research dan dalam Bahasa Belanda disebut sebagai rechtsonderzoek. ${ }^{11}$ Penelitian hukum adalah Penelitian yang dilakukan untuk mencari pemecahan atas isu hukum yang timbul, yaitu memberikan preskripsi mengenai apa yang seyogyanya atas isu yang diajukan. ${ }^{12}$ Dalam penelitian hukum ini, dilakukan untuk menjawab permasalahan isu hukum mengenai kewenangan presiden sebagai lembaga eksekutif dalam pembentukan undang-undang pada sistem presidensiil. Dalam rangka menjawab isu hukum tersebut, maka dalam penelitian hukum ini digunakan argumentasi hukum. Penelitian dengan menggunakan argumentasi hukum adalah penelitian yang ciri utamanya adalah mengkaji pemberlakuan suatu aturan hukum dengan disertai argumentasi/ pertimbangan hukum yang dibuat penegak hukum, serta interpretasi di balik pemberlakuan tersebut. ${ }^{13}$ Dengan demikian, dalam penelitian hukum ini akan diuraikan ratio legis penerapan kebijakan terkait kewenangan presiden sebagai lembaga eksekutif dalam pembentukan undangundang pada sistem presidensiil.

Di dalam penelitain hukum ini, pendekatan yang digunakan adalah pendekatan peraturan perundang-undangan (statute approach), pendekatan konseptual (conceptual approach), dan pendekatan komparasi (comparative approach). Pendekatan peraturan perundangundangan dilakukan dengan menelaah semua peraturan perundang-undangan dan regulasi lain yang berkaitan dengan dengan isu hukum yang ditangani, sehingga berkaitan dengan penelitian ini dapat diketahui ratio legis, dasar ontologis dan landasan filosofis pengaturan yang berkaitan. ${ }^{14}$ Dalam penelitian hukum ini ditelaah peraturan perundang-undangan berkaitan dengan kewenangan presiden sebagai lembaga eksekutif dalam pembentukan undang-undang.

Pendekatan konseptual adalah pendekatan yang beranjak dari pandanganpandangan dan doktrin-doktrin yang berkembang di dalam ilmu huku

\footnotetext{
11 Peter Mahmud Marzuki, "Penelitian Hukum," Yuridika 16, no. 1 (2001): 103.

12 Dyah Ochtorina Susanti and A'an Efendi, Peneltiian Hukum (Jakarta: Sinar Grafika, 2013):1.

13 Bagus Oktafian Abrianto, Xavier Nugraha, and Nathanael Grady, "Perkembangan Gugatan Perbuatan Melanggar Hukum Oleh Pemerintah Pasca-Undang-Undang Nomor 30 Tahun 2014,” Negara Hukum 11, no. 30 (2020): 43-62. 14 Paulus Hadi Suprapto, "Ilmu Hukum (Pendekatan Kajiannya)," Inovatif 2, no. 4 (2010): 7-20.
} 
untuk menganalisa adanya permasalahan hukum. ${ }^{15}$ Dalam penelitian ini, pendekatan konseptual digunakan untuk kewenangan presiden sebagai lembaga eksekutif dalam pembentukan undang-undang.

Pendekatan komparasi adalah pendekatan yang digunakan dengan membandingkan hukum antara satu negara dengan negara lain guna menyingkap latar belakang lahirnya ketentuan hukum tertentu untuk masalah yang sama di kedua negara. ${ }^{16}$ Dalam penelitian ini, hal yang dibandingkan adalah berkaitan dengan kewenangan presiden sebagai lembaga eksekutif dalam pembentukan undangundang di Indonesia dengan Amerika.

\section{PEMBAHASAN}

\subsection{Karakteristik Sistem Pemerintahan Presidensiil}

Dalam ilmu negara (algemeine staatslehre) yang dimaksud dengan sistem pemerintahan ialah sistem hukum ketatanegaraan, baik yang berbentuk monarki maupun republik, yaitu mengenai hubungan antar pemerintah (eksekutif) dan badan yang mewakili rakyat. ${ }^{17}$ Tak jauh berbeda dengan itu, Usep Ranawijaya menegaskan sistem pemeirntahan merupakan sistem hubungan antara eksekutif dan legislatif. ${ }^{18}$ Sejalan dengan pandangan tersebut, Jimly Asshiddiqie mengemukakan sistem pemerintahan berkaitan dengan pengertian regeringsdaad yaitu penyelenggaraan pemeirntahan oleh eksekutif dalam hubungannya dengan fugsi legislatif. ${ }^{19}$ Cara pandang demikian sesuai dengan teori dichotomoy, yaitu legislatif sebagai policy making (taak stelling), sedangkan eksekutif sebagai policy executing (taak verwezenlijking). ${ }^{20}$ Dalam penyelenggaraan fungsi-fungsi Negara tersebut, sejatinya terjadi relasi yang saling mempengaruhi dalam penyelenggaraan kekuasaan eksekutif dan legislatif.

\footnotetext{
15 Mulyadi, "Riset Desain Dalam Metodologi Penelitian," Jurnal Studi Komunikasi dan Media 16, no. 1 (2012): 1928.

16 Peter Mahmud Marzuki, Penelitian Hukum : Edisi Revisi (Jakarta: Kencana Prenada Media Group, 2017):93.

17 Harun Alrasyid, "Kajian Sistem Pemeirntahan Dan Ruang Lingkupnya," Majalah Mahasiswa Universitas Pasundan 3, no. 3 (2002): 1.

18 Usep Ranawijay, Hukum Tata Negara Indonesia: Dasar-Dasarnya (Jakarta: Ghalia Indonesia, 1983):72.

19 Jimly Asshiddiqie, Pokok-Pokok Hukum Tata Negara Indonesia Pasca Reformasi (Jakarta: Buana Ilmu Populer, 2007):311.

${ }^{20}$ Wisnu Nugraha, "Fungsi Legislasi Menurut Undang-Undang Dasar Tahun 1945 (Studi Kasus Badan Legislasi DPR RI Periode 2004-2009)," Binamulia Hukum 7, no. 2 (2018): 157-168.
} 
Perkembangan sistem pemeirntahan parlementer lebih menggambarkan perjuangan mengurangi kekuasaan absolut raja, sementara perkembangan sistem presidensial lebih banyak ditandai dengan bagaimana mengelola hubungan antara presiden (eksekutif) dengan lembaga legislatif. ${ }^{21}$ Karena sama-sama mendapat mandat langsung dari rakyat, sistem presidensial acap kali terjebak dalam ketegangan antara eksekutif dan legislative, apalagi jika kekuatan partai politik mayoritas di lembaga legislatif berbeda dengan partai politik presiden. 22 Pengalaman demikian hampir terjadi pada semua negara yang mempraktikkan sistem presidensial, termasuk Amerika Serikat. Sementara itu, jika patai mayoritas di lembaga legislatif sama dengan partai politik pendukung presiden atau mayoritas partai di lembaga legislatif mendukung presiden, praktik sistem presidensial mudah terperangkap menjadi pemeirntahan otoriter. ${ }^{23}$

Klasifikasi demokrasi modern menurut Kranenburg dapat dibagi tergantung pada hubungan antara organ-organ pemeirntahan yang mewakili tiga fungsi yang berbeda, yaitu:

1. pemerintahan rakyat melalui perwakilan dengan sistem parlementer;

2. pemeirntahan rakyat melalui perwakilan dengan sistem parlementer;

3. pemeirntahan rakyat melalui perwakilan dengan disertai pengawasan langsung oleh rakyat.

Miriam Budiarjo memiliki perspektif yang berbeda, dimana dia membedakan ketiga sistem ini kedalam dua kelompok, yaitu Sistem Parlementer (parliamentary executive) dan sisitem presidensiil dengan fixed excutive atau non parliamentary executive. ${ }^{24}$

Apabila melihat dalam konteks negara Indonesia yang lahir setelah reformasi pada 1999, terdapat beberapa perubahan dalam praktik ketatanegaraan salah satunya mengenai penegasan sistem presidensiil yang dianut oleh Indonesia. Hal ini dilihat berdasarkan UUD NRI 1945. Dalam sistem UUD NRI 1945, pelaksanaan kedaulatan rakyat dilaksanakan menurut prosedur konstitusional yang ditetapkan

\footnotetext{
${ }^{21}$ Saldi Isra, “Hubungan Presiden Dan DPR,” Jurnal Konstitusi 10, no. 3 (2013): 399-416.

22 Ibid.

23 Ibid.

24 Muliadi Anangkota, "Klasifikasi Sistem Pemerintahan: Perspektif Pemerintahan Modern Kekinian Muliadi Anangkota," CosmoGov: Jurnal Ilmu Pemerintahan 3, no. 2 (2017).
} 
berdasarkan hukum dan konstitusi (constitusinal democracy). ${ }^{25}$ Kedaulatan rakyat di Indonesia diselenggarakan secara langsug dan melelui sistem perwakilan. ${ }^{26}$ Kedaulatan rakyat di Indonesia diselenggarakan secara langsung, hal ini diwujudkan melalui pemilihan presiden, wakil presiden beserta anggota lembaga perwakilan yang dilaksanakan secara langsung. Selain itu, kedaulatan rakyat juga diwujudkan melalui pelaksanaan hak dan kebebasan berpendapat. Hal-hal tersebut kemudian berimplikasi kepada perubahan sistem pemerintahan secara keseluruhan.

Pada awalnya, penggunaan sistem presidensiil diberlakukan oleh Amerika Serikat, dengan ciri-ciri sebagai berikut: ${ }^{27}$

1. Presiden adalah pemegang kekuasaan eksekutif tunggal, dan sebagai penyelenggara pemerintahan yang bertanggung jawab serta memiliki berbagai wewenang konstitusional yang bersifat prerogatif yang lazim melekat pada jabatan kepala negara (head of state);

2. Presiden tidak bertanggungjawab kepada kongres sehingga tidak dapat dikenai mosi tidak percaya . Oleh karena Presiden tidak dipilih dan dingkat oleh Kongres, maka pemilihan Presiden dilakukan secara langsung oleh rakyat, walaupun secara formal dipilih badan pemilih (electoral college);

3. Dalam menduduki masa jabatannya, Presiden memiliki waktu selama empat tahun dan hanya dapat dipilih untuk dua kali masa jabatan berturutturut (8 tahun); dan

4. Pada sistem presidensiil di Amerika Serikat, Presiden dapat diberhentikan dari jabatannya melalui proses impeachment karena alasan telah melakukan pengkhianatan, atau melakukan kejahatan yang serius.

Menurut Bagir Manan, sistem presidensil yang diterapkan di Indonesia sebelum amandemen UUD 1945, mempunyai ciri-ciri yang hampir mirip dengan sistem Presidensiil di Amerika Serikat, dengan beberapa ciri khusus, seperti Presiden dipilih oleh badan perwakilan rakyat yan dalam hal ini adalah MPR. Kemudian Presiden tunduk dan bertanggung jawab kepada MPR, tetapi tidak tunduk dan bertanggung jawab kepadda DPR. Oleh karena Presiden diangkat oleh MPR, maka Presiden dapat

25 Ofis Rikardo, "Penerapan Kedaulatan Rakyat Di Dalam Pemilihan Umum Di Indonesia Berdasarkan UndangUndang Dasar Negara Republik Indonesia Tahun 1945," Jurnal Hukum Sasana 6, no. 1 (2020): 51-71.

26 Ibid.

27 Bachtiar Baital, "Pertanggungjawaban Penggunaan Hak Prerogatif Presiden Di Bidang Yudikatif Dalam Menjamin Kemerdekaan Kekuasaan Kehakiman," Jurnal Cita Hukum 2, no. 1 (2014). 
pula diberhentikan oleh MPR dan dapat dipilih kembali tanpa batas setiap 5 tahun sekali.

Konsep sistem Presidensiil berdasarkan UUD 1945 pra amandemen, sejatinya dapat dikatakan tidak murni, karena telah menunjukkan beberapa elemen-elemen sistem parlementer. Hal tersebut dapat dilihat dalam konsep pertanggungjawaban Presiden kepada MPR yang termasuk dalam pengertian lembaga parlemen dengan kemungkinan pemberian kewenangan kepadanya untuk memberhentikan Presiden dari jabatannya. Oleh karena itu, dengan diamandemennya konstitusi Negara Republik Indonesia hingga yang keempat klainya, khususnya dengan diadopsinya sistem pemilihan Presiden langsung dan dilakukannya perubahan sruktural maupun fungsional terhadap kelembagaan MPR, maka sistem pemeirntahan yang dianut oleh Indonesia menjadi lebih mencerminkan sistem pemerintahan presidensiil. Giovanni Sartori menegaskan bahwa sistem politik dikatakan pemeirntahan presidensial jika presiden: ${ }^{28}$

(i) result from populer election;

(ii) during his or her pre-establish tenure cannot be discharged by a parliamentary vote; and

(iii) heads or otherwise directs the government that he or she appoints.

Adapun beberapa keuntungan sistem pemerintahan presidensil adalah:29

1. adanya stabilitas eksekutif yang didasarkan oleh jaminan terhadap kepastian lamanya jabatan presiden;

2. pemilihan umum presiden dapat dianggap lebih demokratis daripada pemilihan secara tidak langsung baik formal maupun secara informal sebagaimana eksekutif dalam sistem parlementer; dan

3. terdapat adanya pemisahan kekuasaan yang berarti pembatasan terhadap kekuasaan eksekutif yang merupakan proteksi yang sangat berharga untuk kebebasan individu terhadap pemerintahan yang otoriter.

Meskipun memiliki beberapa keuntungan, sejatinya system pemerintahan presidensil juga memeliki beberapa kelemahan, yaitu adanya kemungkinan

28 Yulion Zalpa, "Semi Presidensil : Paradoks Sistem Pemerintahan Di Indonesia," Tamaddun: Jurnal Kebudayaan dan Sastra Islam 20, no. 2 (2018): 50-59.

29 Dinoroy Marganda Aritonang, "Penerapan Sistem Presidensil Di Indonesia Pasca Amandemen UUD 1945," Mimbar Hukum 22, no. 2 (2010): 391-407. 
terjadinya kebuntuan (deadlock) dan kelumpuhan akibat konflik antar parlemen dan eksekutif. Hal ini tentu saja tidak dapat dihindarkan mengingat kedudukan kedua lembaga tersebut sama-sama independen. Sehingga, ketika terjadi adanya konflik maka tidak ada institusi yang dapat menyelesaikan masalah tersebut. Konflik tersebut juga dapat terjadi misalnya dalam melaksanakan fungsi legislasi, yang mana kemungkinan terjadinya deadlock antara pemerintah dan badan perwakilan tidak dapat dipungkiri.

Jika dianalisis, sejatinya dapat ditarik benang merah, bahwa secara garis besar sistem pemeirntahan presidensial merupakan sistem pemerintahan yang mencirikan adanya pemisahan kekuasaan antara lembaga eksekutif dan juga lembaga legislatif. Sehingga, adanya pemisahan kekuasaan tersebut Presiden sebagai kepala negara dan juga kepala pemerintahan tidak dapat membubarkan parlemen. Begitupula halnya dengan parlemen juga tidak dapat menjatuhkan Presiden. Dan baik parlemen maupun presiden keduanya dipilihan berdasarkan pemilihan secara langsung oleh rakyat. Karena Presiden dipilih oleh rakyat, sehingga Presiden tidak bertanggungjawab kepada parlemen.

\subsection{Komparasi Proses Pembentukan Peraturan Perundang-undangan Pada Sistem Pemerintahan Presidensiil di Indonesia dengan Amerika}

Fungsi Legislasi merupakan fungsi untuk membentuk undang-undang (wetgevende functie/law making function) yang notabene merupakan fungsi pengaturan (regelende function). Menurut Jimly Asshiddiqie, fungsi legislasi memiliki empat bentuk kegiatan yaitu: ${ }^{30}$

1. prakarasa pembuatan undang-undang;

2. pembahasan rancangan undang-undang;

3. persetujuan atas pengesahan rancangan undang-undang; dan

4. pemberian persetujuan pengikatan atau ratifikasi atas perjanjian atau persetujuan internasional dan dokumen-dokumen hukum yang mengikat lainnya. Fungsi legislasi dalam sistem presidensial didasarkan pada adanya pemisahan kekuasaan yang tegas antara eksekutif dan legislatif.

30 Jimly Asshiddiqie, Pengantar Ilmu Hukum Tata Negara (Jakarta: PT. RajaGrafindo Persada, 2009):299. 
Dengan demikian, dalam sistem presidensial, badan legislatif menentukan agendanya sendiri, membahas dan menyetujui rancangan undang-undang pun sendiri pula. Artinya, bahwa fungsi legislasi dalam sistem presidensial merupakan wewenang eksklusif dari badan legislatif. Namun, dalam sistem negara modern, ada hubungan fungsional antara eksekutif dan legislatif. Bahkan, dalam fungsi legislasi di Indonesia dilakukan secara bersama-sama antara ekskutif dan legislatif.

Dalam karakter yang dijelaskan tersebut, kekuasaan legislatif memiliki peranan yang lebih dominan dalam menjalankan fungsi legislasi ketimbang kekuasaan eksekutif. Namun, karakter tersebut tidak mutlak dapat dijalankan sepenuhnya karena beberapa faktor seperti kurangnya sumber daya, pengaruh sistem kepartaian dan faktor lain. Sehingga, karakter khas dalam sistem presidensial, Presiden memiliki hak veto yaitu berupa hak untuk menolak suatu undang-undang yang telah ditetapkan oleh kekuasaan legislatif.

Berkaitan dengan fungsi legislasi yang dimiliki oleh badan perwakilan sekaligus eksekutif, maka untuk mengetahui secara rinci variasi proses penyusunan peraturan perundang-undangan pada sistem pemerintahan presidensill, digunakan analisis komparatif dengan menjawab pertanyaan sebagai berikut: ${ }^{31}$

How do ideas for new legislation enter the system-and from where?; Who preliminarily explicates these idea-and how?; Who decides, and by what criteria and procedures, to spend scarce drafting resource on some bills-and not others?; Who employs what procedures to ensure that bills meet formal standards, and do not contradict other laws?; Who does what kinds of research to determine the bills' details?; And how do input and feedback institutions grant to some people and not others, the power to supply information to those preparing bills-about facts, various theories, and various groups' claims and demands?.

Dengan menjawab berbagai pertanyaan tersebut akan dapat memudahkan perbandingan antara penyusunan peraturan perundang-undangan dalam yuridiksi manapun. Karena, seperti kita ketahui, peraturan perundang-undangan sebagai cerminan ekspresi nilai masyarakat dibuat untuk menjaga ketertiban masyarakat,

31 Ekawestri Prajwalita Widiati, "Local Legislative Drafting in the Unitary States: A Comparison Between Indonesia and Philippines," Yuridika 28, no. 3 (2013): 304-313. 
sehingga tidak ada satu negarapun yang tidak memiliki fungsi legislasi sebagai salah satu fungsi utama dalam kehidupan berbangsa dan bernegara.

\section{A. Indonesia}

Kewenangan dalam mengatur atau membuat aturan (regeling) pada dasarnya merupakan wewenang yang dimiliki lembaga legislatif sebagai wakil rakyat untuk menentukan aturan yang mengikat bagi setiap warga negara. Di Indonesia, dalam hal kewenangan pembentukan undang-undang sebagai produk hukum tertulis, Pasal 5 ayat (1), dan Pasal 20 UUD NRI 1945 menyebutkan sebagai berikut;

Pasal 5

(1) Presiden berhak mengajukan rancangan undang-undang kepada Dewan Perwakilan Rakyat.

Pasal 20

(1) Dewan Perwakilan Rakyat memegang kekuasaan membentuk undangundang.

a. Setiap rancangan undang-undang dibahas oleh Dewan Perwakilan Rakyat dan Presiden untuk mendapat persetujuan bersama.

b. Jika rancangan undang-undang itu tidak mendapat persetujuan bersama, rancangan undang-undang itu tidak boleh diajukan lagi dalam persidangan Dewan Perwakilan Rakyat masa itu.

c. Presiden mengesahkan rancangan undang-undang yang telah disetujui bersama untuk menjadi undang-undang.

d. Dalam hal rancangan undang-undang yang telah disetujui bersama tersebut tidak disahkan oleh Presiden dalam waktu tiga puluh hari semenjak rancangan undang-undang tersebut disetujui, rancangan undang-undang tersebut sah untuk menjadi undang-undang dan wajib diundangkan.

Ketentuan Pasal 5 ayat (1) dan Pasal 20 UUD NRI 1945 tersebut bermakna bahwa kekuasaan membentuk undang-undang dimiliki oleh Dewan Perwakilan Rakyat bersama Presiden. Jika dicermati, dalam Pasal 20 UUD 1945 sebelum amandemen dan Pasal 20 UUD NRI 1945 setelah amandemen terdapat pergeseran kekuasaan legislatif yang semula berada di tangan Presiden menjadi berpindah di tangan DPR. Dengan adanya perubahan tersebut, menurut Jimly Asshiddiqie, DPR lah 
yang dapat dinamakan sebagai legislator atau lembaga pembentuk undang-undang, sedangkan Presiden merupakan co-legislator. ${ }^{32}$ DPR lah yang merupakan legislator utama atau "primary legislator", "principal legislator" atau "main legislator", bukan lagi Presiden seperti sebelumnya. Namun, pendapat berbeda dikemukakan oleh Maria Farida Indrati, yang menyebutkan bahwa peranan Presiden dalam pembentukan Undang-Undang terlihat lebih kuat ${ }^{33}$, jika dihubungkan dengan rumusan dalam Pasal 20 ayat (4) UUD NRI 1945 yang menyatakan bahwa: "Presiden mengesahkan rancangan undang-undang yang telah disetujui bersama untuk menjadi undang-undang".

Ketentuan ini membuktikan, bahwa sebenarnya fungsi legislasi yang menjadi wewenang DPR tidak mutlak, tetapi lebih kepada fungsi yang dilakukan bersamasama antara DPR dan Presiden (joint function), sehingga bukan merupakan wewenang penuh karena kedudukan keduanya setara dan seimbang. Dengan kedudukan yang sama-sama berimbang tersebut, maka fungsi legislasi di Indonesia dipegang oleh DPR dan Presiden mulai dari perancangan sampai persetujuan bersama.

Setiap RUU harus mendapat persetujuan bersama antara DPR dan Presiden. Apabila tidak mendapatkan persetujuan bersama, maka RUU tersebut tidak boleh diajukan dalam persidangan berikutnya. Apabila disetujui bersama, maka RUU tersebut akan disahkan oleh Presiden. Kata persetujuan antara DPR dan Presiden adalah pengesahan yang bersifat materiil, sedangkan pengesahan oleh Presiden hanya bersifat formil.

Dengan semangat check and balances, setelah perubahan UUD 1945 dalam struktur parlemen dibentuklah kamar penyeimbang sebagai representatif daerah yang disebut dengan Dewan Perwakilan Daerah (DPD). DPD diatur dalam ketentuan Pasal 22D UUD 1945.Kelahiran DPD merupakan sebagai kamar kedua (bicameral) dalam sistem ketatanegaraan Indonesia. Sehingga menyerupai keberadaan Senat di Amerika Serikat. Dalam fungsi legislasi, peranan DPD tidak terlalu kuat bahkan sangat lemah.Sehingga hanya sebagai lembaga pendukung bagi DPR. Hal ini dapat

\footnotetext{
32 Jimly Asshiddiqie, Perihal Undang-Undang Di Indonesia (Jakarta: Sekretariat Jenderal dan Kepaniteraan MK RI, 2006):316.

${ }^{33}$ Maria Farida Indrati S, Ilmu Perundang-Undangan 1 Jenis, Fungsi, Dan Materi Muatan (Yogyakarta: Kansius, 2007):188.
} 
kita lihat dari kewenangan yang dimiliki oleh DPD hanya sebatas pada mengajukan RUU dan memberikan pertimbangan kepada DPR serta ikut membahas suatu RUU.DPD tidak ikut serta untuk menyetujui suatu RUU. Peranan DPR lebih dominan ketimbang DPD, sehingga Indonesia bisa dikatakan menganut soft bicameral. ${ }^{34}$

Pengaturan dalam Pasal 20 UUD NRI 1945 tersebut berbeda dengan model legislasi dalam sistem presidensial. Terkait dengan model itu, Saldi Isra, mengemukakan karakter proses legislasi atau pembentukan undang-undang dalam sistem presidensial sebagai berikut: 35

1. Pertama, proses awal persiapan rancangan undang-undang, eksekutif dan (anggota) legislatif punya kesempatan yang sama untuk mengajukan rancangan undang-undang;

2. Kedua, semua rancangan undang-undang dibahas dan disetujui lembaga legislatif;

3. Ketiga, karena pembahasan dan persetujuan menjadi wewenang eksklusif lembaga legislatif, pemegang kekuasaan eksekutif dapat mengajukan keberatan atau menolak (dalam bentuk veto) rancangan undang-undang yang disetujui legislatif;

4. Keempat, sesuai dengan prinsip supremacy of legislative power pembentukan undang-undang dalam sistem presidensial, keberatan atau penolakan eksekutif dapat ditolak kembali oleh legislatif atas veto presiden, rancangan diumumkan dan dinyatakan berlaku menjadi undang-undang.

Di dalam Pasal 5 dan Pasal 20 UUD NRI 1945, sejatinya telah memuat adanya pemisahan kekuasaan (separation of power) dengan mengutamakan prinsip check and balances antar cabang-cabang kekuasaan negara. Pada bidang legislatif, eksekutif, dan yudisial terdapat adanya pemisahan kekuasaan yang tegas. DPR sebagai lembaga negara yang memiliki fungsi legislasilah yang mewakili rakyat yang berdaulat dalam membentuk undang-undang. Sedangkan pemerintah sebagai pihak eksekutif hanya bertindak sebagai pelaksana undang-undang. Apabila pemerintah menetapkan suatu peraturan perundang-undangan, maka kewenangan pembentukan

34 Taufik Hidayat, "Penerapan Sistem Soft Bikameral Dalam Parlemen Di Indonesia," JOM Fakultas Hukum 2, no. 2 (2015): 1-14.

35 Isra, Pergeseran Fungsi Legislasi; Menguatnya Model Legislasi Parlementer Dalam Sistem Presidensial Indonesia:235. 
peraturan perundang-undangan tersebut harus didasarkan atas pendelegasian kewenangan yang berasal dari pembentuk undang-undang (legislative delegation of the rule-making process). Produk hukum yang dibentuk oleh lembaga-lembaga sekunder ini sebagai pejabat atau lembaga eksekutif biasa disebut pula dengan istilah executive acts atau produk eksekutif. Dengan kata lain, DPR adalah pembentuk undang-undang, sedangkan Presiden merupakan pelaksana undang-undang.

Secara garis besar proses pembentukan Undang-Undang terdiri atas beberapa tahap, yaitu: ${ }^{36}$

1. Proses persiapan pembentukan undang-undang, yang dalam UndangUndang Nomor 15 Tahun 2019 Tentang Perubahan Atas Undang-Undang Nomor 12 Tahun 2011 Tentang Pembentukan Peraturan PerundangUndangan (UU 15/2019) dimulai dengan tahapan perencanaan peraturan perundang-undangan. Perencanaan penyusunan Undang-Undang ini dilakukan dalam Program Legislasi Nasional. Dalam penyusunan UndangUndang berdasarkan Prolegnas tersebut, rancangan undang-undang yang dimaksud dapat berasal dari Pemerintah (Presiden), berdasarkan Pasal 5 ayat (1) UUD NRI 1945 dan Pasal 43 ayat (1) UU 15/2019, dari Dewan Perwakilan Rakyat, berdasarkan Pasal 20 ayat (1) UUD NRI 1945 dan Pasal 43 ayat (1) UU 15/2019, dari Anggota Dewan Perwakilan Rakyat, berdasarkan Pasal 21 UUD NRI 1945, dan dari Dewan Perwakilan Daerah, berdasarkan Pasal 22D UUD NRI 1945 dan Pasal 43 ayat (2) UU UU $15 / 2019$.

2. Proses pembahasan rancangan undang-undang dilakukan oleh Dewan Perwakilan Rakyat bersama Presiden atau menteri yang ditugasi. Pembahasan RUU tersebut berdasarkan Pasal 67 UU 15/2019 dilaksanakan dalam dua tingkat pembicaraan, yaitu pembicaraan tingkat I yang dilakukan dalam rapat komisi, rapat gabungan komisi, rapat Badan Legislasi, rapat Badan Anggaran, atau Panitia Khusus. Sedangkan pembicaraan tingkat II dilaksanakan dalam rapat paripurna.

3. Proses pengesahan rancangan undang-undang oleh Presiden, dan

36 Maria Farida Indrati S, Ilmu Perundang-Undangan 2 Proses Dan Teknik Penyusunan (Yogyakarta: Kanisius, 2007):11. 
4. Proses pengundangan (oleh Menteri yang menyelenggarakan urusan pemerintahan di bidang hukum).

Berdasarkan prosedur tersebut, dapat dilihat secara singkat, bahwa pembentukan undang-undang merupakan wewenang yang dimiliki oleh lembaga legislatif yang dalam hal ini adalah DPR RI yang dilakukan bersama Presiden sesuai dengan amanat konstitusi.

Telah dijelaskan dalam pembahasan sebelumnya bahwa dalam hal melaksanakan fungsi legislasi, Presiden berhak mengajukan rancangan undangundang serta melakukan pembahasan berkaitan dengan penyusunan undang-undang bersama dengan DPR RI. Sekalipun Presiden dan DPR sama-sama mendapat mandat langsung dari rakyat melalui pemilihan umum, pada tataran praktik yang terjadi sesungguhnya adalah perebutan pengaruh antara presiden dan DPR di hadapan rakyat. Bahkan, bangunan koalisi besar (over size coalition) pun tidak menjadi jaminan bahwa penegang kekuasaan legislatif tidak akan menganggu pihak eksekutif. Dalam fungsi legislasi, UUD 1945 mmberikan posisis seimbang (fifty-fifty) antara pemeirntah dan DPR dalam membahas dan menyetujui rancangan undang-undang. Namun dalam praktik, pemeirntah terlihat begitu cepat menyerah terhadap keinginan sebagian kekuatan politik di DPR. Berkaitan dengan pembentukan peraturan perundang-undangan masih dimungkinkan terjadinya deadlock antara Presiden dan DPR Meskipun dalam hal ini berdasarkan konstitusi UUD NRI 1945 menyebutkan bahwa Presidenlah yang memiliki kewenangan dalam mengesahkan rancangan undang-undang yang telah disetujui menjadi undang-undang. Namun, terhadap pengaturan mnegenai hal ini tidak dapat diambil kesimpulan bahwa Presiden memiliki kewenangan yang lebih besar dibanding badan legislatif. Hal ini disebabkan pada Pasal 20 ayat (5) menjelaskan bahwa dalam hal rancangan undangundang yang telah disetujui bersama tersebut tidak disahkan oleh Presiden dalam waktu tiga puluh hari semnejak rancangan undang-undang tersebut disetujui, rancangan undang-undang tersebut sah menjadi undang-undang dan wajib diundangkan.

Dalam konteks ketatanegaraan Indonesia dengan sistem presidensial, fungsi legislasi tetap mengacu pada adanya pemisahan kekuasaan antara eksekutif dan legislatif, namun tidak diterapkan secara mutlak. Hal ini ditandai dengan adanya 
wewenang Presiden untuk ikut serta dalam mengajukan suatu rancangan undangundang, membahas bersama dengan DPR untuk mencapai persetujuan bersama, serta mengesahkannya menjadi undang-undang.

\section{B. Amerika Serikat}

Di Amerika, prinsip pemisahan kekuasaan yang dicetuskan oleh Montesquieu (legislatif, eksekutif dan judisiil), sejatinya oleh Amerika Serikat dicoba dituangkan di dalam konstitusi. Di Amerika, Kongres merupakan satu-satunya pemegang kekuasaan membentuk undang-undang. Presiden semata-mata menjalankan kekuasaan eksekutif dan tidak mempunyau kekuasaan membentuk atau tidak mempunyai hak inisiatif dan tidak mempunyai hak untuk turut serta membahas undang-undang. Article I Konstitusi Amerika Serikat menyebutkan bahwa: "All legislative powers here in granted shall be reted a conggress of the United State, which shall consist of a Senate and House of Representative".

Pembentuk konstitusi (framers of the constitution) Amerika Serikat (AS) berupaya mendesain sistem pemerintahan yang berbeda dengan sistem parlementer Inggris. Menurut CF Strong, the conception of independence of the executive from the legislative merupakan salah satu konsep yang disepakati para pendiri AS. ${ }^{37}$ Pemisahan tersebut diatur dalam Article I dan Article II Konstitusi Amerika Serikat. Tidak hanya pemisahan antara legislatif dan eksekutif, posisi presiden sebagai kepala negara sekaligus kepala pemerintahan pertama kali muncul di AS pada abad ke-18. Menurut Harus Alrasid, jabatan presiden dalam negara berbentuk republik demikian merupakan hasil Konvensi Federal pada 1787 yang menyebutkan: ${ }^{38}$ "The executive power shall be vested in a President of the United States of America...". Sebagaimana dinyatakan Jack Bell, sekalipun memilih presiden dan menolak raja, para perancang konstitusi Amerika Serikat memutuskan bahwa presiden harus mempunyai kekuatan yang memadai untuk menyelesaikan rumitnya masalah bangsa (the executive must have the power to cope with the problems of national). ${ }^{39}$ Karena itu, dirancanglah konstitusi yang memberikan kekuasaan besar kepada presiden, namun dengan tetap menutup hadirnya pemimpin sejenis raja yang tirani.

37 C.F. Strong, Modern Political Constitution An Introduction to the Comparative Study of Their History and Existing Form (London: Sidwick \& Jackson Ltd, 1975):223.

38 Isra, "Hubungan Presiden Dan DPR."

39 Jack Bell, The Presidency: Office of Power (Boston: Allyn and Bacon Inc, 1967). 
Fungsi legislasi dalam sistem ketatanegaraan Amerika Serikat didasarkan pada adanya pemisahan yang tegas antara legislatif dan eksekutif. Di Amerika Serikat, tidak ada satu pasal pun dalam konstitusi yang menentukan Presiden Amerika Serikat berwenang untuk mengajukan suatu RUU. ${ }^{40}$ Dengan demikian, di Amerika Serikat doktrin pemisahan kekuasaan, yakni adanya pemisahan yang tegas antara kekuasaan eksekutif dan legislatif terutama dalam pembentukan undang-undang. Dengan dasar tersebut, pemegang fungsi legislasi dalam konstitusi Amerika Serikat adalah Senate dan House of Representatives, tanpa melibatkan Presiden sebagai pihak ekskeutif. ${ }^{41}$ Presiden dan jajaran eksekutif tidak terlibat sama sekali dalam fungsi legislasi, baik mengajukan RUU atau ikut membahas suatu UU. Menurut C.F. Strong, satu-satunya hubungan antara eksekutif dan legislatif dalam praktek sistem presidensial Amerika Serikat adalah melalui laporan Presiden (Presidential Message) dan tak seorangpun pejabat kabinet Presiden diizinkan turut seta dalam suatu majelis lembaga legislatif. ${ }^{42}$ Fungsi legislasi di Amerika Serikat hanya dipegang oleh dua kaar dalam kongres yakni Senate dan House of Respresentatives. Struktur parlemen Amerika Serikat bersifat bicameral, dimana kedua kekuasaan memiliki yang beribang satu sama dengan lainnya (strong bicameral). ${ }^{43}$ Dengan dasar tersebut, setiap undang-undang di Amerika, harus mendapat persetujuan di kedua kamar tersebut. Di dalam Article 1 Section 7 angka 2 Konstitusi Amerika Serikat diatur bahwa:

Every bill which shall passed the House of Representatives and the Senate, before it become the law, be presented to the Presidentof the United States; If he approve he shall sign it, but if not he shall return it, with his objection to the house in which it shall have originated, who shall enter the objection at large on their journal, and proceed to consider it. If after such consideration two third of that House shall agree to pass the bill, it sent together with the objection, to other house, by which it shall likewise be considered, and if approved by two

40 I Made Pasak Diantha, Tiga Tipe Pokok Sistem Pemerintahan Dalam Demokrasi Modern (Bandung: Abardin, 1990).

41 Jaka Prima, "Perbandingan Kewenangan Badan Legislatif Di Indonesia Dan Amerika Serikat," Negara dan Keadilan 8, no. 1 (2019): 1-12.

42 CF Strong, Modern Political Constitution: An Introduction to The Comparative Study of Their History and Existing Form (London: Sidwick\&Jackson Limited, n.d.):238.

43 Yokotani Yokotani, "Sistem Bikameral Di Lembaga Legislatif Berdasarkan Tugas Dan Kewenangan Dewan Perwakilan Daerah (Perbandingan Dengan Amerika Serikat, Inggris, Dan Argentina)," PROGRESIF: Jurnal Hukum 11, no. 1 (2018): 1850-1866. 
thirds of that House, it shal become a law. But in all such cases the votes of both Houses shal be determined by yeas and nays, and the name of the persons voting for and against tha Bill shall be entered on the journal of each House respectively. If any Bill shall not be returned by the President within ten day (Sunday excepted) after it shall have been presented to him, the same shall be a law, in like manner as if he had signed it, unless the Congressby their adjournment prevent its return in which case it shall not be a law.

Berdasarkan konstitusi Amerika tersebut, maka setiap undang-undang harus mendapatkan persetujuan dari kedua kamar dalam kongres yakni Senate dan House of Representatives dan sebelum menjadi undang-undang harus dimajukan ke Presiden untuk mendapatkan pengesahan (Approving).Jika sepakat maka undangundang tersebut akan ditanda tangani, dan apabila tidak maka Presiden akan mengembalikannya dengan memberikan alasan-alasan penolakan. Penolakan Presiden terhadap bill yang sudah disetujui oleh kedua kamar dalam kongres Amerika Serikat biasa disebut dengan veto. Veto merupakan wewenang konstitusional yang dimiliki oleh Presiden Amerika Serikat untuk mengesahkan suatu bill. ${ }^{44}$ Dalam teori, praktek seperti ini disebut dengan presidential veto. Tetapi, disamping itu, hak veto yang dimiliki oleh Presiden Amerika Serikat tersebut dapat dibatalkan oleh Senate dan House of Representative melalui pranata yang disebut dengan legislative veto. Dalam konstitusi Amerika Serikat istilah penolakan ini disebut dengan override. Override yang dilakukan oleh kedu kamar baik Senat ataupun House of Representative dengan syarat memenuhi $2 / 3$ suara sari maisngmaisng kamar. Apabila syarat 2/3 tersebut terpenuhi, maka bill tersebut menjadi undang-undang (if approved by two third of that House, it shall become a law).

Hak veto dalam dalam sistem pemerintahan presidensial di Amerika Serikat dapat dilakukan dengan dua cara, yaitu reguler veto dan pocket veto. Regular veto merupakan jenis veto yang paling sering digunakan oleh Presiden Amerika Serikat. Veto jenis ini diajukan ketika House of Representative dan Senate dalam persidangan,

\footnotetext{
44 Efi Yulistyowati, Endah Pujiastuti, and Tri Mulyani, "Penerapan Konsep Trias Politica Dalam Sistem Pemerintahan Republik Indonesia: Komparatif Atas Undang-Undang Dasar Tahun 1945 Sebelum Dan Sesudah Amandemen," Jurnal Dinamika Sosial Budaya 18, no. 3 (2016): 336.
} 
maka rancangan undang-undang tersebut sah menjadi undang-undang. ${ }^{45}$ Pocket Veto terjadi karena tenggat 10 hari untuk mengajukan keberatan bagi Presiden bertepatan dengan House of Representative dan Senat tidak dalam masa sidang. Kalaupaun Presiden mengajukan keberatan, House of Representative dan Senate tidak dapat melakukan override. Sehingga dengan pocket veto, rancangan undang-undang tidak dapat menjadi undang-undang. ${ }^{46}$

Dalam praktek ketatanegaraan yang berkembang meskipun Presiden tidak mempunyai wewenang membentuk undang-undang, namun makin banyak gagasan membntuk undang-undang yang berasal dari Pemeirntah (Presiden). Hal ini dimungkinkan dengan memanfaatkan ketentuan dalam Article 2 Chapter 3, Konstitusi Amerika Serikat yang menyebutkan: "He shall from time ti time give to the Congress Information of the state of the Union, and recommend to their consideration such measures as he shall judge necessary and expedient..."

\section{PENUTUP}

\subsection{Kesimpulan}

Fungsi legislasi merupakan fungsi pembentukan undang-undang. Dengan adanya ajaran pemisahan kekuasaan, maka antara legislatif dan eksekutif dipisahkan secara tegas antara fungsi dan lembaganya. Namun pada beberapa negara, pemisahan kekuasaan ini tidak diterapkan secara mutlak. Di Indonesia sendiri, yang menganut sistem pemerintahan presidensiil apabila dibandingkan dengan Amerika Serikat yang juga menganut sistem pemerintaha presidensiil terdapat perbedaan yang jelas dalam keterlibatan Presiden sebagai lembaga eksekutif dalam pemebntukan undang-undang.

Dalam struktur ketatanegaraan Indonesia, pemegang fungsi legislasi adalah Dewan Perwakilan Rakyat yang dilakukan secara bersama-sama dengan Presiden untuk kemudian mendapatkan persetujuan bersama. Apabila tidak mendapatkan persetujuan bersama maka RUU tersebut tidak dapat menjadi undang-undang. Sehingga, fungsi legislasi di Indonesia bersifat Joint Function.

45 Bagus Oktafian Abrianto, Xavier Nugraha, and Risdiana Izzaty, "Hak Konstitusional Lembaga Kepresidenan Dalam Penolakan Pengesahan RUU APBN Oleh DPR," Jurnal Ius Kajian Hukum dan Keadilan 7, no. 3 (2019): 519533. 46 Ibid. 
Sedangkan pembentukan peraturan perundang-undangan di Amerika Serikat dipegang oleh dua kamar yang memiliki peran dan fungsi legislasi yang seimbang dan setara antara satu dengan yang lain. Kedua kamar tersebut yaitu House of Representative dan Senat. Semua undang-undang (bill) terlebih dahulu harus disetujui oleh kedua kamar tersebut. Sedangkan Presiden hanya berwenang untuk memberikan hak veto pada rancangan undang-undang yang telah disetujui oleh senat dan HoR. Rancangan undang-undang yang telah disetujui oleh Senat dan House of Representative (presidentila veto), akan tetapi veto Presiden tersebut akan menjadi gugur apabila dalam kedua kamar baik Senat maupun DPR dengan 2/3 suara menolak veto Presiden tersebut (override), maka rancangan undang-undang tersebut menjadi undang-undang.

Sehingga, dalam hal pembentukan peraturan perundang-undangan, Presiden memiliki kewenangannya masing-masing. Di Indonesia, Presiden dapat mengusulkan peraturan perundang-undangan hingga melakukan pembahasan bersama dengan DPR selaku lembaga legislatif. Sedangkan di Amerika Serikat, Presiden tidak memiliki wewenang untuk turut serta membahasa undang-undang. Namun, Presiden memiliki hak veto yang dapat digunakan untuk menyatakan ketidaksetujuannya terhadap peraturan perundang-undangan hasil pembahasan Senat dan HoR. Sehingga, potensi terjadinya deadlock akan lebih tinggi terjadi d sistem pemebntukan peraturan perundang-undangan di AS ketimbang di Indonesia.

\subsection{Saran}

Adanya perbedaan kewenangan eksekutif dalam pembentukan undang-undang antara Indonesia dengan Amerika Serikat, meskipun keduanya sama-sama merupakan negara yang menerapkan sistem presidensil sejatinya terjadi, karena adanya perbedaan, yaitu Indonesia merupakan Negara soft bicameral, sedangkan Amerika Serikat strong bicameral. Oleh sebab itu, tidak bisa secara an sich dipersamakan, namun justru seharusnya perbedaan yang ada tersebut disempurnakan dengan tetap memperhatikan ciri khas dari Negara tersebut. 


\section{DAFTAR PUSTAKA}

Abrianto, Bagus Oktafian, Xavier Nugraha, and Nathanael Grady. "Perkembangan Gugatan Perbuatan Melanggar Hukum Oleh Pemerintah Pasca-Undang-Undang Nomor 30 Tahun 2014." Negara Hukum 11, no. 30 (2020): 43-62.

Abrianto, Bagus Oktafian, Xavier Nugraha, and Risdiana Izzaty. "Hak Konstitusional Lembaga Kepresidenan Dalam Penolakan Pengesahan RUU APBN Oleh DPR." Jurnal Ius Kajian Hukum dan Keadilan 7, no. 3 (2019): 519-533.

Alrasyid, Harun. "Kajian Sistem Pemeirntahan Dan Ruang Lingkupnya." Majalah Mahasiswa Universitas Pasundan 3, no. 3 (2002): 1.

Aritonang, Dinoroy Marganda. "Penerapan Sistem Presidensil Di Indonesia Pasca Amandemen UUD 1945." Mimbar Hukum 22, no. 2 (2010): 391-407.

Asshiddiqie, Jimly. Pengantar Ilmu Hukum Tata Negara. Jakarta: PT. RajaGrafindo Persada, 2009.

- - - Perihal Undang-Undang Di Indonesia. Jakarta: Sekretariat Jenderal dan Kepaniteraan MK RI, 2006.

-_- Pokok-Pokok Hukum Tata Negara Indonesia Pasca Reformasi. Jakarta: Buana Ilmu Populer, 2007.

Azed, Abdul Bari. "Mewujudkan Sistem Presidensial Murni Di Indonesia: Sebuah Gagasan Penyempurnaan Sistem Ketatanegaraan Indonesia” 5, no. 2 (2013): 4478.

Baital, Bachtiar. "Pertanggungjawaban Penggunaan Hak Prerogatif Presiden Di Bidang Yudikatif Dalam Menjamin Kemerdekaan Kekuasaan Kehakiman." Jurnal Cita Hukum 2, no. 1 (2014).

Diantha, I Made Pasak. Tiga Tipe Pokok Sistem Pemerintahan Dalam Demokrasi Modern. Bandung: Abardin, 1990.

Hadi, Syofyan. "Fungsi Legislasi Dalam Sistem Pemerintahan Presidensil (Studi Perbandingan Indonesia Dan Amerika Serikat)." DIH Jurnal Ilmu Hukum 9, no. 18 (2013): 78-84.

Isra, Saldi. "Hubungan Presiden Dan DPR.” Jurnal Konstitusi 10, no. 3 (2013): 399416.

-_- Pergeseran Fungsi Legislasi; Menguatnya Model Legislasi Parlementer Dalam Sistem Presidensial Indonesia. Jakarta: PT. Raja Grafindo Persada, 2010.

Izzaty, Risdiana, and Xavier Nugraha. "Perwujudan Pemilu Yang Luber Jurdil Melalui Validitas Daftar Pemilih Tetap." Jurnal Suara Hukum 1, no. 2 (2019): 155-171. http://jurnal.untagsmg.ac.id/index.php/mia/article/view/726.

Jack Bell. The Presidency: Office of Power. Boston: Allyn and Bacon Inc, 1967.

Manan, Bagir. Lembaga Kepresidenan. Yogyakarta: Gama Media, 1999.

Marzuki, Peter Mahmud. Penelitian Hukum : Edisi Revisi. Jakarta: Kencana Prenada Media 
_—_. "Penelitian Hukum.” Yuridika 16, no. 1 (2001): 103.

Muliadi Anangkota. "Klasifikasi Sistem Pemerintahan: Perspektif Pemerintahan Modern Kekinian Muliadi Anangkota." CosmoGov: Jurnal Ilmu Pemerintahan 3, no. 2 (2017).

Mulyadi. "Riset Desain Dalam Metodologi Penelitian." Jurnal Studi Komunikasi dan Media 16, no. 1 (2012): 19-28.

Nalle, Victor Imanuel W. "Kewenangan Yudikatif Dalam Pengujian Peraturan Kebijakan." Jurnal Yudisial 6, no. 1 (2013): 33-47.

Nugraha, Wisnu. "Fungsi Legislasi Menurut Undang-Undang Dasar Tahun 1945 (Studi Kasus Badan Legislasi DPR RI Periode 2004-2009).” Binamulia Hukum 7, no. 2 (2018): 157-168.

Ofis Rikardo. "Penerapan Kedaulatan Rakyat Di Dalam Pemilihan Umum Di Indonesia Berdasarkan Undang-Undang Dasar Negara Republik Indonesia Tahun 1945." Jurnal Hukum Sasana 6, no. 1 (2020): 51-71.

Prima, Jaka. "Perbandingan Kewenangan Badan Legislatif Di Indonesia Dan Amerika Serikat." Negara dan Keadilan 8, no. 1 (2019): 1-12.

Ranawijay, Usep. Hukum Tata Negara Indonesia: Dasar-Dasarnya. Jakarta: Ghalia Indonesia, 1983.

S, Laurensius Arliman. "Penyelenggaraan Sistem Presidensil Berdasarkan Konstitusi Yang Pernah Berlaku Di Indonesia.” Muhakkamah 4, no. 2 (2019): 77-89.

S, Maria Farida Indrati. Ilmu Perundang-Undangan 1 Jenis, Fungsi, Dan Materi Muatan. Yogyakarta: Kansius, 2007.

-_- Ilmu Perundang-Undangan 2 Proses Dan Teknik Penyusunan. Yogyakarta: Kanisius, 2007.

Strong, C.F. Modern Political Constitution An Introduction to the Comparative Study of Their History and Existing Form. London: Sidwick \& Jackson Ltd, 1975.

Strong, CF. Modern Political Constitution: An Introduction to The Comparative Study of Their History and Existing Form. London: Sidwick\&Jackson Limited, n.d.

Suparto. "Teori Pemisahan Kekuasaan Dan Konstitusi Menurut Negara Barat Dan Islam." Hukum Islam 19, no. 1 (2019): 134-149.

Suprapto, Paulus Hadi. "Ilmu Hukum (Pendekatan Kajiannya)." Inovatif 2, no. 4 (2010): 7-20.

Susanti, Dyah Ochtorina, and A'an Efendi. Peneltiian Hukum. Jakarta: Sinar Grafika, 2013.

Taufik Hidayat. "Penerapan Sistem Soft Bikameral Dalam Parlemen Di Indonesia." JOM Fakultas Hukum 2, no. 2 (2015): 1-14.

Widiati, Ekawestri Prajwalita. "Local Legislative Drafting in the Unitary States: A Comparison Between Indonesia and Philippines." Yuridika 28, no. 3 (2013): 304-313.

Wiyanto, Andy. "Pertanggungjawaban Presiden Dan Mahkamah Konstitusi." Jurnal 
Konstitusi 7, no. 3 (2010): 209-231.

Yokotani, Yokotani. "Sistem Bikameral Di Lembaga Legislatif Berdasarkan Tugas Dan Kewenangan Dewan Perwakilan Daerah (Perbandingan Dengan Amerika Serikat, Inggris, Dan Argentina)." PROGRESIF: Jurnal Hukum 11, no. 1 (2018): 1850-1866.

Yulistyowati, Efi, Endah Pujiastuti, and Tri Mulyani. "Penerapan Konsep Trias Politica Dalam Sistem Pemerintahan Republik Indonesia: Komparatif Atas UndangUndang Dasar Tahun 1945 Sebelum Dan Sesudah Amandemen." Jurnal Dinamika Sosial Budaya 18, no. 3 (2016): 336.

Zalpa, Yulion. "Semi Presidensil: Paradoks Sistem Pemerintahan Di Indonesia." Tamaddun: Jurnal Kebudayaan dan Sastra Islam 20, no. 2 (2018): 50-59.

Zulkarnaen. "Kemitraan Antara Eksekutif Dan Legislatif Dalam Sistem Pemerintahan Indonesia Berdasarkan Undang-Undang Dasar Tahun 1945." Galuh Justisi 8, no. 2 (2020): 245-260. 